1 Environmental context of the Kura-Araxes culture

2 Connor, S.E. and Kvavadze, E.V.

3

4 This is a draft version of a manuscript published in Paléorient 40: 9-20 (2014).

5 Please note that there may be differences between this version and the final

6 published version. The authors will be happy to provide copies on request. 


\section{ENVIRONMENTAL CONTEXT OF THE KURA-ARAXES CULTURE}
Abstract: The Kura-Araxes culture flourished in the South Caucasus and neighbouring regions during the $4^{\text {th }}-3^{\text {rd }}$ millennia BC. More than in previous periods, this period saw a greater concentration of populations in the region's vast volcanic highlands.
Palaeoecological records suggest that deciduous forests reached their maximum extent at the time, triggered by changes in temperature and precipitation. In this contribution, the environmental conditions that accompanied the Kura-Araxes culture are reconstructed from palaeoecological data from the region, placing settlement patterns in context and providing insights into human-environment interactions during this period of social and environmental change.

Keywords: Kura-Araxes; past climate; environmental change; palaeovegetation; Western Asia.

\section{INTRODUCTION}

From around $3500 \mathrm{BC}$, one of the most distinctive material cultures in prehistoric Western Asia began to appear in the South Caucasus, Eastern Anatolia, north-western Iran and the Upper Euphrates Valley (Sagona, this volume). Along with the striking uniformity of its pottery and domestic spaces, a defining characteristic of the KuraAraxes culture was its geographic extent (Burney 1958). Kura-Araxes settlements appeared across the vast highlands of the interior of Eastern Anatolia and the South Caucasus (Fig. 1), a marked shift away from the lowland focus of the cultures that had gone before (Chataigner 1995).

The Kura-Araxes heartland extended from the slopes of the Greater Caucasus in the north, through the densely settled Kura and Araxes valleys, and fanning out past the great lakes of Van and Urmia and along a wide arc bordered by the Taurus Mountains in the south. Today these highland zones are characterised by a fiercely continental climate - harsh winters and hot summers - and almost endless expanses of grassland vegetation. Wood is scarce and dung fuel is commonly used in domestic settings. But was this the case in the past? Was the Kura-Araxes settlement pattern influenced environmental changes occurring in the $4^{\text {th }}$ millennium BC? Or, indeed, did the KuraAraxes people exert an influence over their surrounding environment?

While there can be no simple answer to these complex questions, this paper attempts to piece together the diverse lines of evidence for the environments that existed at the time of the Kura-Araxes culture (mid- $4^{\text {th }}$ to mid-late $3^{\text {rd }}$ millennia BC). This evidence includes analyses of isotopes, pollen and other microfossils from lake sediments and cave deposits. These findings will be placed in the broader context of environmental 
changes occurring in Western Asia during the same period. Archaeobotanical evidence for Kura-Araxes plant use will be covered in a later chapter (Hovsepyan, this volume).

The paper begins with a brief description of the present-day environments of the KuraAraxes, as it is only through this contemporary lens that the environments of the past can be imagined. It then moves to a discussion of the scale, significance, limitations and uncertainties associated with the palaeoenvironmental evidence. Finally it attempts to reconstruct the environments that developed around and alongside the Kura-Araxes culture, providing a broad-scale context for settlement patterns and human-environment interactions in a period of remarkable social and environmental change.

\section{REGIONAL GEOGRAPHY}

In every sense of the term, the South Caucasus, Eastern Anatolia and north-western Iran constitute a 'crossroads' - between cultures, languages, ancient trade routes, climate zones, biogeographical regions, political units and tectonic plates. Over the last 40 million years or so, the entire area has been squashed, folded and warped as the Arabian Plate has pushed up against its Eurasian neighbour (Y1lmaz et al. 1998). The tectonic movements that are responsible for frequent earthquakes in the present day have, over millions of years, uplifted sediments from a Jurassic sea to great heights along the Greater Caucasus Range, plunged parts of Colchis into the Black Sea and folded Eastern Anatolia into a concertina of east-west valleys.

Volcanic activity associated with these crustal movements has created vast lava plateaux and pyroclastic deposits in the highlands of Armenia, Southern Georgia, Eastern Anatolia and Iranian Azerbaijan, punctuated by large lake basins and statuesque volcanic cones such as Mount Ararat (5156 m). Many of these volcanic centres were active through the Neogene and Quaternary periods and into historical times (Y1lmaz et al. 1998; Karakhanian et al. 2002). There are also extensive areas of metamorphic and sedimentary rock interspersed through the highlands, contributing to a complex geological scene. At the same time as mountains were being built by tectonic uplift and volcanic activity, erosion by wind, water and mountain glaciers was shaping the landscape, cutting deep gorges into older rocks and filling wide valleys with alluvial sediment (e.g. Collins et al. 2005). The lowlands of Azerbaijan and Western Georgia are composed of recent sediments eroded from the surrounding mountains.

Present-day climates in the highlands are distinguished by their continentality (Türkeş 1996; Djamali et al. 2011a). The Pontic Mountains and the Lesser Caucasus tend to buffer the highland interiors from the moderating maritime influence of the Black Sea. Steep temperature gradients exist in relation to altitude, with the highest parts of the Armenian Plateau experiencing an annual average temperature below freezing, while in the lowland plains of the Kura and Araxes Rivers, average temperatures can exceed $12^{\circ} \mathrm{C}$ (Bagdasarian 1961). Higher annual temperatures occur in the Upper Euphrates Valley. Perhaps more significant are the seasonal fluctuations in temperature, which 
can vary between +40 and $-40^{\circ} \mathrm{C}$ in some places (FMI 2001, cited in Collins et al. 2005). Precipitation also follows steep gradients in relation to proximity to the Black Sea and the presence or absence of mountain ranges to intercept orographic rainfall. Much of the region receives between 400 and $800 \mathrm{~mm}$ of annual precipitation. Drier areas that receive less than $200 \mathrm{~mm}$ occur along the Araxes Valley and the western Caspian coast. The southern coast of the Caspian is notably humid.

Rainfall seasonality is also prominent, both intra- and inter-annually, driven by latitudinal shifts in the moisture-bearing westerlies and the relative positions of highpressure systems (Roberts \& Wright 1993; Litt et al. 2009). In the southern part of the Kura-Araxes region, such as around Van and Urmia, rainfall is typically highest from January-April, with a pronounced dry spell from July-September (Fig. 2). In the central part, around Yerevan, Erzurum and Kars, rainfall peaks in April-May, again with a dry spell from July-September. In the northern part, around Tsalka and Tbilisi, rainfall peaks in May-June and, although there is a summer decrease, the major dry spell falls between December and February (Gerasimov 1964). While these characteristics apply to the recent climate, it should be remembered that the conditions prevailing at the time of the Kura-Araxes culture were possibly quite different (Djamali et al. 2010; Roberts et al. 2011).

Another aspect of the landscape that is likely to have changed over the last 5000 years is the vegetation (Fig. 3). The typical plateau lands cape today is virtually treeless, save for a few poplars or willows along streamsides. In terms of plant geography, the region is where the Euro-Siberian region's Euxinian-Hyrcanian forest flora meets the IranoTuranian steppe flora (Davis 1965; Zohary 1973). The Irano-Turanian steppes dominate the present-day highland landscape, with grasses, especially feather grass, prevalent in areas not used intensively for agriculture (Gulisashvili 1964). The scattered patches of open oak-juniper and pine woodland found on mountainsides stretching from the Armenian Plateau across to the Pontus and Taurus Mountains may be remnants of an earlier and more continuous woodland cover in this area (Takhtajan 1986; Bottema 1995). Dense forests of beech occur along the northeastern edge of the highlands, with forests of Georgian oak (Quercus iberica) at lower altitudes. Pine, spruce and fir forests are distributed along the Pontus Range fronting the Black Sea, the coast and mountainsides of which are densely forested and contain a number of Tertiary-relict species found nowhere else on earth. Somewhat similar forests occur on the southern end of the Caspian Sea (Browicz 1989; Akhani et al. 2010). Semidesert and lowland steppe vegetation is found in the driest parts of the region, especially in the east (Walter 1974).

Vegetation in many parts of the region follows an altitudinal zonation, from semidesertsteppes in the lowlands, to xerophytic scrub vegetation in the foothills, grading into oak forests at middle elevations, dense beech forests in the upper forest belt, open oak, pine or birch woodlands at the upper treeline and then into mountain steppes (Nakhutsrishvili 1999). These patterns vary depending on slope, aspect, climate, soils and past human activity. The highest elevations, where not covered with permanent snow, harbour 
alpine vegetation. The intermixture of the Euro-Siberian and Irano-Turanian floras combines with steep climatic gradients, rugged topography and a long history geological isolation to create extraordinary levels of plant biodiversity, making the Caucasus a global biodiversity hotspot (Myers et al. 2000). The Kura-Araxes region is also home to a variety of wild cereals, legumes, grape vines and fruit trees, predecessors of today's staple crops and a valuable genetic resource (Ketskhoveli 1959; Bardsley \& Thomas 2005). Collectively, these factors, along with the rich archaeological record, make the study of the region's vegetation history a worthwhile endeavour.

\section{ENVIRONMENTAL ARTEFACTS - THE NATURE OF THE EVIDENCE}

Those who study past vegetation - palaeoecologists - have much in common with their colleagues in archaeology. Both trawl through deposits, often stratified, looking for objects that may help build a picture of life in the past; except that in the case of palaeoecology, it is plant or animal life that is the object of study. Like archaeological sites, the 'site catchment' of palaeoecological sites can vary enormously. To pollen analysts this catchment is known as the source area (Davis 2000). The source area of large lakes is very large, gathering pollen from hundreds, if not thousands, of kilometres from the region around the lake and depositing that mixed assemblage in the sediments. For a small lake only $100 \mathrm{~m}$ across, the source-area is much smaller, reflecting the local vegetation growing around the site (Davis 2000).

Wetlands such as bogs, swamps and fens have an additional consideration in that they also collect pollen from the wetland vegetation itself, which can pose problems for interpretation if the wetland vegetation does not produce pollen that are distinctly different from the pollen produced in the surrounding landscape. This is true of the Kura-Araxes region, where both wetlands and mountain steppes may be dominated by grasses (Connor 2011). As yet there is no effective way to distinguish between the pollen of most wetland and steppe grasses; however, wheat and other cultivated cereal grasses do produce distinctively patterned and shaped pollen grains (Beug 2004; Tweddle et al. 2005).

Many pollen types can be confidently assigned to a plant genus or even species. For example, hornbeam, walnut, wingnut, olive, holly, spruce, fir, beech and chestnut all produce pollen that can be linked to a single plant species in large parts of the Caucasus region (Connor 2011). The abundance of these types in sediments is both a function of the pollen source-area and the pollination strategy of the plant. Wind-pollinating trees like pines and oaks can produce enormous quantities of pollen, whereas insectpollinated species, including the major fruit trees of the Rosaceae family, disperse few pollen which are unlikely to appear in lake sediments unless present locally (Woldring \& Cappers 2001; Ramezani et al. 2013). Pine pollen will be present in almost all sediments, whether pine trees are present nearby or not (Kvavadze 1993). Difficulties arise when attempting to differentiate between pine forest and mountain steppe using pollen analysis (Connor \& Kvavadze 2008). 
Radiocarbon dating has revolutionised palaeoecology in the same way it has archaeology. Environmental changes that may have once been assumed as synchronous across large geographic areas have proven to be time-transgressive. For example, the transition from steppe to forest vegetation that occurred in much of Europe at the beginning of the Holocene (9750 BC) does not occur in some parts of inner Anatolia and Iran until many thousands of years later, if at all (Roberts 2002). These findings could have major consequences for the way we understand past cultures and their environmental context.

Large uncertainties still surround reported radiocarbon dates from palaeoecological records. The beta-counting procedures used in earlier records required large samples and were prone to contamination by younger humic acids or older carbonates. The advent of Accelerator Mass Spectrometer (AMS) techniques has allowed smaller, less contaminated samples to be dated. Even so, the absence of datable organic material and the presence of contaminating carbonates in the sediments of the largest lakes make dating these records particularly difficult (Roberts 2002; Djamali et al. 2010). In one case, the sediments from the Sögütlü mire in Eastern Anatolia were studied and dated with the primary aim of providing a solid chronological framework for the neighbouring Lake Van sediment records, which lacked reliable radiocarbon dates (Bottema 1995). Mire sediments often contain whole seeds and other organic remains that can provide very precise radiometric dates. Whether those dates accurately reflect of the age of the sediment is another matter.

These general considerations set the scene for the following section, which presents an overview of the evidence for past vegetation, climate and environment leading up to and during the Kura-Araxes culture.

\section{PRELUDE TO THE KURA-ARAXES PERIOD}

The Kura-Araxes culture followed a period of rather dramatic environmental change in the Black Sea and Eastern Mediterranean regions. At some time between 6400 and $6250 \mathrm{BC}$, or perhaps earlier, the Black Sea was transformed from a freshwater lake to a semi-marine basin as the Mediterranean spilled over through the Bosporus (Turney \& Brown 2007; Badertscher et al. 2011). This change had lasting effects on the moisture balance and vegetation of the lands around the Black Sea (Wick et al. 2003; Shumilovskikh et al. 2012; Connor et al. 2013). The North Atlantic climate system was also upset by a rapid cooling event around the same time, with possible consequences for Neolithic populations in Western Asia (Weninger et al. 2006; Turney \& Brown 2007). While the timing and extent of these changes is still debated and imprecise, there is now ample evidence that parts of the region experienced a wet climatic phase around 6000-6500 BC, initiating the gradual retraction of arid steppes (Roberts et al. 2011). 
In the highlands, replacement of steppes by woodlands and forests was generally a gradual process, if it occurred at all (Fig. 4). Areas close by the main regional moisture source of the Black Sea saw the earliest forest expansion, such as the sites of Didajara and Gomnistba in southwestern Georgia (altitude 1850 m; Fig. 1, Table 1), where forests were more or less fully developed by 7500 BC (Margalitadze 1995). Further inland, at Lake Paravani (2073 m) on Southern Georgia's Javakheti Plateau, a substantial increase in pine pollen is timed to between 6400 and $6100 \mathrm{BC}$ (Messager et al. 2013). On the Armenian Plateau, new data from Zarishat Mire (2116 m) indicate that the major increase in pine pollen occurred there around $5000 \mathrm{BC}$ (Joannin et al. 2014). In northwestern Iran, the increase in oak pollen around Lake Urmia (1280 m) culminated around $6000-5000 \mathrm{BC}$, producing vegetation similar to what presently exists in the area (Bottema 1986; van Zeist \& Bottema 1991). At Lake Van in Eastern Anatolia (1674 m), despite a slow increase in tree pollen since the beginning of the Holocene and a steady rise since $6000 \mathrm{BC}$, the first major peak in oak pollen does not occur until around 4000-3000 BC (Wick et al. 2003; Litt et al. 2009).

These examples serve to demonstrate the complex history of vegetation development in the highlands of the South Caucasus and Anatolia prior to the arrival of the KuraAraxes culture. Climatic factors certainly played a defining role, especially changes in rainfall seasonality (Stevens et al. 2001; Djamali et al. 2010). The vegetation that developed was also influenced by the migration rates of trees as they spread out from glacial refugia in the lowlands, the degree of soil development and the effects of herbivores and firestick-wielding humans. Fire, in particular, may have been a common feature of highland landscapes during the Late Chalcolithic (Connor 2011; Joannin et al. 2014). Around parts of the Eastern Mediterranean, evidence is emerging of a widespread arid phase - from 3300-3000 BC - that has been linked to the ChalcolithicEarly Bronze Age transition (Roberts et al. 2011). Was this also the impetus for cultural change in the Caucasus?

\section{ENVIRONMENTAL CHANGE AND THE KURA-ARAXES CULTURE}

The general uniformity of the Kura-Araxes cultural assemblage has led to the suggestion that its settlement pattern was achieved through human migration (Burney \& Lang 1971; Sagona 2011). Kushnareva (1997) argued that increasing aridity in the lowlands was the main impetus for movement to higher elevations. Indeed, there is some evidence for a distinct climatic fluctuation around 3500-3000 BC (Joannin et al. 2014). This evidence includes a precipitation decrease registered in the Ispani record from the coast of Western Georgia (Connor \& Kvavadze 2008), changes in forest composition at the middle elevation sites of Cheliagele and Tsavkisi (Ammann 2010; Connor 2011), increasing charcoal in the highland records from Zarishat, Imera and Aligol, as well as slowed sedimentation rates in several highland lakes (Margalitadze 1995; Connor 2011; Messager et al. 2013; Joannin et al. 2014). These changes are less apparent in the regional-scale vegetation records from the larger lakes of Van, Urmia 
and Paravani. There are, however, indications of synchronous climatic oscillations in oxygen isotope records from Lake Van, as well as the Sofular Cave in northern Anatolia (Badertscher et al. 2011; Roberts et al. 2011).

Limitations on sampling resolution and radiocarbon chronologies mean that the sequence of environmental changes that accompanied the spread of Kura-Araxes communities remains vague. Nevertheless, there are some consistent patterns worthy of note and it is hoped that future research will refine or redefine the coarse picture painted here. After $3000 \mathrm{BC}$, forest cover in most areas of the Kura-Araxes region reached its maximum Holocene extent (Fig. 4). Tree-lines ascended to higher elevations and scrub vegetation at lower elevations transformed into dense forest (Connor \& Kvavadze 2005; Messager et al. 2013). Lake levels peaked in Lake Van (Wick et al. 2003), at the same time as lakes in central Anatolia began to dry out and Caspian Sea levels fell (Roberts et al. 2011; Leroy et al. 2013). Clearly the regional moisture balance was shifting across the whole of Western Asia. The highland steppes became warmer and wetter (Joannin et al. 2014), indicated by the increase in oak pollen and onset of rapid sedimentation in the Tsalka Plateau lakes of Southern Georgia (Connor 2011). Drought-intolerant spruce began to expand its range eastward and into the upper catchment of the Kura River (Margalitadze 1995). Charcoal particles declined in sediment records across the region, signalling a change in fire occurrence that may have been mitigated by climate, human activity or both.

\section{THE CONTEXT OF KURA-ARAXES SETTLEMENTS}

Let us move now from changes in time to variations in space. Thanks to the recent publication of pollen records from Lake Paravani and Zarishat there are now sufficient data - despite enormous gaps and chronological uncertainties - to attempt an approximation of the spatial distribution of the vegetation at the height of the KuraAraxes culture (Fig. 3). This attempt is based on the region's present-day vegetation and bioclimatic characteristics, combined with the few pollen data that exist, as has been previously attempted for considerable areas of the Near East (van Zeist \& Bottema 1991). Pollen data from each site were translated into vegetation types using an indicator species approach (described in Connor \& Kvavadze 2008). Any differences between the present and past vegetation were extrapolated from individual sites to cover bioclimatically similar areas. The resulting map (Fig. 3) is therefore a working hypothesis and remains to be tested by further empirical research. Four areas within the Kura-Araxes region have sufficient information to warrant further discussion: northwestern Iran, Eastern Anatolia, the Armenian Plateau and Georgia.

Lake Urmia provides the best evidence for past vegetation on the northwest sector of the Iranian Plateau (Bottema 1986). Other key sites - Mirabad and Zeribar - are located further south, beyond the geographic scope of this discussion. Only two radiocarbon dates are available for the Urmia record, but, because the record lacks major changes, these are sufficient to reconstruct the vegetation during the Kura-Araxes period. Small 
quantities of tree pollen against a background of abundant grass and wormwood pollen suggest a semidesert-steppe landscape, much like the present one. Well-dated pollen data from Lake Almalou ( $2500 \mathrm{~m}$ ), an infilled crater $85 \mathrm{~km}$ east of Lake Urmia, suggest relative stability in the highland steppe vegetation over the last 3400 years, despite changing agricultural and arboricultural activities at lower elevations and within the crater itself (Djamali et al. 2009, 2011b). While the pollen source area of Urmia is vast compared to Almalou, the similarities in their recent vegetation histories suggest that semidesert-steppe prevailed on local and regional scales. A similar kind of vegetation persisted through the last 6000 years in higher parts of the Talysh Mountains of NW Iran, as demonstrated by a recent analysis of beetle remains and pollen in sediments from Lake Neor (Ponel et al. 2013).

Eastern Anatolia's palaeoenvironmental centrepiece is Lake Van (van Zeist \& Woldring 1978; Litt et al. 2009). The most detailed record, a 13,000-year high-resolution pollen and isotopic analysis, was produced by Wick et al. (2003). According to their interpretation, forest-steppe vegetation existed around Lake Van at the time of the KuraAraxes culture. Numerical classification places this into the category of oak-xerophyte vegetation, wholly consistent with that interpretation. Today's landscape is similarly classified as oak-xerophyte, even though human activities over recent millennia have reduced the extent of oak woodland. The same patterns are reflected in the neighbouring Söğütlü record (Bottema 1995), indicating that vegetation changes here occurred on local and regional scales. On this basis, van Zeist and Bottema (1991) suggested that the mid-Holocene vegetation to the south and west of Lake Van was woodland (also termed 'savanna parkland': Roberts 2002), whereas steppes, with woodland patches at higher elevations, prevailed to the north and east.

In the northeastern part of Eastern Anatolia lies the Pasinler Valley. Excavations at Sos Höyük, a tell dating back to the Late Chalcolithic (Sagona, this volume), have spawned a number of palaeoenvironmental studies in the Pasinler Valley. Newton (2004) and Longford et al. (2009) used carbonised wood remains to reconstruct the composition of the surrounding forests during the Bronze Age. The prevalence of oak and pine wood remains suggested to these authors that deciduous forest-steppe vegetation covered the plains and foothills, with pine forest on the surrounding mountain slopes. The only published pollen record from the Pasinler Valley comes from fluvial sediments that may have been affected by sediment reworking or selective preservation (Collins et al. 2005). Nonetheless, the mid-Holocene peak in pine pollen and subsequent decline are consistent with the regional pattern of gradual deforestation.

In northwest Armenia, the available data indicate that mountain grasslands prevailed at higher elevations (Zarishat: Joannin et al. 2014), judging from the prevalence of grass and herb pollen in sediments there. Analogous pollen assemblages from Lake Sevan (1898 m: Saiadian 1985) suggest that similar vegetation existed in eastern-central Armenia during the Early Bronze Age. Palaeoethnobotanical remains from the site of Tsaghkasar, near Mt Aragats, are thought to reflect an environment much like the present one (Hovsepyan 2011). Open woodlands of juniper and oak, which still exist in 
the Sevan basin (Gulisashvili 1964), were probably more widespread than they are today. Vegetation presumably was zoned according to altitude, as it is today, with alpine vegetation at higher elevations, steppic grasslands below that and mixed deciduous-coniferous forests of varied composition below the treeline (Saiadian 1999). As yet, there are insufficient palaeoecological data from Armenia to provide a precise definition of the altitudinal position of these vegetation belts in the past.

A good deal more information is available for Georgia. The Bronze Age was almost certainly the period of maximum forest extent throughout the area of Kura-Araxes settlements. This is attested in pollen and non-pollen palynomorph records from lake and wetland sediments, as well as from Bronze Age archaeological sites (Kvavadze et al. 2004; Kvavadze \& Kakhiani 2010; Kakhiani et al. 2013). Lake Paravani possesses such a large surface area $\left(37 \mathrm{~km}^{2}\right)$ that its pollen record represents a regional picture (Fig. 5). Compared to today, the Kura-Araxes period here had a greater extent of mixed deciduous-coniferous forests, which may have ascended upslope to elevations at or near that of the lake basin (Messager et al. 2013; see also Arabuli et al. 2008). Fir, a rare tree in Southern Georgia today, seems to have been a common constituent of these ecosystems. Mixed forests were also well established at an elevation of $1850 \mathrm{~m}$ on the well-watered western slopes of the Trialeti and Arsiani Ranges. These areas are now among pine, spruce and beech forest (Margalitadze 1995).

It also seems certain that oak trees were present over large parts of the Tsalka Plateau (approx. $1500 \mathrm{~m}$ elevation) where none exist today (Connor \& Sagona 2007). Scattered trees are more likely than a dense forest given the pollen evidence and the volcanic soils of the plateaux, which tend to favour grasses over trees. At middle elevation sites, such as Cheliagele and Tsavkisi (Fig. 6), dense deciduous forests were developed where today we find forest-steppe and cleared vegetation (Connor \& Kvavadze 2008; Ammann 2010). Dry scrub and semidesert-steppe vegetation were presumably pushed to lower elevations during the Kura-Araxes period (Kvavadze 1999). Grazing areas were also affected by forest expansion - fungal spores indicative of grazing at Tsavkisi were far fewer during the densely forested Bronze Age than the lightly wooded Chalcolithic, suggesting the displacement of pastures by forest (Connor \& Kvavadze 2008).

Palaeoclimatic reconstructions for the Bronze Age suggest that the highlands were warmer and perhaps drier than at present, while the lowlands were likely warmer and wetter (Table 2; Wick et al. 2003; Connor 2011). Compared to areas further to the south and west, where the climate of the time was apparently becoming drier and more seasonally variable (Stevens et al. 2001; Roberts et al. 2011), the highlands of Eastern Anatolia, northwestern Iran and the South Caucasus may have provided more reliable rainfall and a more stable base for agro-pastoral economies.

Much more remains to be learned about the environmental context of the Kura-Araxes culture. Recent palaeoecological work in Georgia has greatly refined our knowledge of past environments. It now remains to extend the same approaches to other parts of the 
region. Armenia and Eastern Anatolia in particular, with their abundance of volcanic lakes and wetlands, have tremendous potential to close the large geographic gaps in knowledge in the areas where Kura-Araxes settlement densities may have been highest. A better understanding of how prehistoric cultures adapted to a rapidly changing, warming environment can only be of benefit to today's societies, which are faced with similar challenges.

\section{ACKNOWLEDGEMENTS}

The authors would like to acknowledge the many years of support we received from our great friend, the late Dr Eristo Kvavadze (1940-2013), who, along with his enormous contributions to the field of invertebrate zoology, helped develop the analysis of fossilised insect remains in the Caucasus and assisted in many of the field expeditions that ultimately provided the palaeoecological data reviewed here.

\section{Simon CONNOR}

School of Geography and Environmental Science

Faculty of Arts, Monash University

VIC 3800, AUSTRALIA.

Simon.Connor@monash.edu

\section{Eliso KVAVADZE}

Institute of Palaeobiology

Georgian National Museum

4 Niagvris St.

Tbilisi 0105, GEORGIA.

ekvavadze@mail.ru

\section{BIBLIOGRAPHY}

AkHani, H., DJamali, M., Ghorbanalizadeh, A. and RAmeZAni, E.

2010 Plant biodiversity of Hyrcanian relict forests, N Iran: an overview of the flora, vegetation, palaeoecology and conservation. Pakistan Journal of Botany 42: 231-258.

\section{AmMANN, B.}

2010 Reconstruction of vegetation as a tool to understand resources of the past. In: Massery, C. (ed.) News of Ancient Colchis: 15-20. Adamiantis Press, Tbilisi.

Arabuli, G.J., Kvavadze, E.V., Kikodze, D., Connor, S.E., Kvavadze, E., Bagaturia, N., Murvanidze, M. and Arabuli, T. 
2008 The krummholz beech woods of Mt Tavkvetili (Javakheti Plateau, southern Georgia) - a relict ecosystem. Proceedings of the Institute of Zoology (Tbilisi) 23: 194-213.

BAdertscher, S., Fleitmann, D., Cheng, H., Edwards, R.L. GÖKTÜRK, O.M., ZumbÜHL, A., LEUENBERGER, M. and TÜYSÜZ, O.

2011 Pleistocene water intrusions from the Mediterranean and Caspian seas into the Black Sea. Nature Geoscience 4: 236-239.

BAGDASARIAN, A.B. (ed.)

1961 Atlas of the Armenian Soviet Socialist Republic. Academy of Science of the Armenian SSR and GUGK, Yerevan-Moscow (in Russian).

BARDSLEY, D. and THOMAS, I.

2005 Valuing local wheat landraces for agrobiodiversity conservation in Northeast Turkey. Agriculture, Ecosystems and Environment 106: 407-412.

BEUG, H.-J.

2004 Leitfaden der Pollenbestimmung für Mitteleuropa und angrenzende Gebiete. Verlag Dr Friedrich Pfeil, Munich.

BOTTEMA, S.

1986 A Late Quaternary pollen diagram from Lake Urmia (northwestern Iran). Review of Palaeobotany and Palynology 47: 241-261.

1995 Holocene vegetation of the Van area: palynological and chronological evidence from Söğütlü, Turkey. Vegetation History and Archaeobotany 4: 187-193.

BROWICZ, K.

1989 Chorology of the Euxianian and Hyrcanian element in the woody flora of Asia. Plant Systematics and Evolution 162: 305-314.

BURNEY, C.A.

1958 Eastern Anatolia in the Chalcolithic and Early Bronze Age. Anatolian Studies 8: 157-209.

BURNEY, C. and LANG, D.M.

1971 The Peoples of the Hills: Ancient Ararat and Caucasus. Weidenfeld and Nicolson, London.

ChATAigner, C.

1995 La Transcaucasie au Néolithique et au Chalcolithique. Tempus Reparatum, Oxford (BAR International Series 624).

Collins, P.E.F., Rust, D.J., BAYRAKTUTAN, M.S. and Turner, S.D.

2005 Fluvial stratigraphy and palaeoenvironments in the Pasinler Basin, eastern Turkey. Quaternary International 140/141: 121-134. 
CONNOR, S.E.

2011 A Promethean Legacy: Late Quaternary vegetation history of Southern Georgia, Caucasus. Peeters, Leuven (Ancient Near Eastern Studies Supplement 34).

CONNOR, S. and KVAVADZE, E.

2005 Climatic and human influences on vegetation dynamics around Tbilisi over the past 6000 years. Proceedings of the Georgian Academy of Sciences, Biological Series 3: 64-76.

2008 Modelling late Quaternary changes in plant distribution, vegetation and climate using pollen data from Georgia, Caucasus. Journal of Biogeography 36: 529545.

Connor, S.E., Ross, S., Sobotkova, A., Herries, A.I.R., Mooney, S.D., Longford, C. and ILIEV, I.

2013 Environmental conditions in the SE Balkans since the Last Glacial Maximum and their influence on the spread of agriculture into Europe. Quaternary Science Reviews 68: 200-215.

CONNOR, S. and SAGONA, A.

2007 Environment and society in the late prehistory of southern Georgia, Caucasus. In: LyONNET, B. (ed.) Les Cultures du Caucase (IVe-IIIe millénaires avant notre ère): leurs relations avec le Proche-Orient: 21-36. CNRS Éditions, Paris.

CONNOR, S.E, ThOMAs, I. and KVAVADZE, E.V.

2007 A 5600-yr history of changing vegetation, sea levels and human impacts from the Black Sea coast of Georgia. The Holocene 17: 25-36.

DAVIS, M.B.

2000 Palynology after Y2K - understanding the source area of pollen in sediments. Annual Review of Earth and Planetary Science 28: 1-18.

DAVIS, P.H. (ed.)

1965 Flora of Turkey and the East Aegean Islands, volume I. University Press, Edinburgh.

De Klerk, P., Haberl, A., KaffKe, A., Krebs, M., Matchutadze, I., Minke, M., SCHULZ, J. and JoOSTEN, H.

2009 Vegetation history and environmental development since ca $6000 \mathrm{cal}$ yr BP in and around Ispani 2 (Kolkheti lowlands, Georgia). Quaternary Science Reviews 28: 890-910.

Djamali, M., Akhani, H., Andrieu-Ponel, V., Braconnot, P., Brewer, S., DE Beaulieu, J.-L., Fleitmann, D., Fleury, J., Gasse, F., Guibal, F., Jackson, S.T., LÉzine, A.-M., Médail, F., Ponel, P., Roberts, N. and Stevens, L.

2010 Indian summer monsoon variations could have affected the early-Holocene woodland expansion in the Near East. The Holocene 20: 813-820. 

understanding the modern vegetation and biogeography. Ecologia Mediterranea 37: 91-114.

Djamali, M., De Beaulieu, J.-L., Andrieu-Ponel, V., Berberian, M., Miller, N.F., 489 Gandoin, E., Lahijani, H., Shah-Hosseini, M., Ponel, P., Mojtaba, S. and Guiter, F.

Djamali, M., Miller, N.F., Ramezani, E., Andrieu-Ponel, V., De Beaulieu, J.-L.,

Berberian, M., Guibal, F., Lahijani, H., LaK, R. and Ponel, P.

2009 A late Holocene pollen record from Lake Almalou in NW Iran: evidence for $2011 \mathrm{~b}$ Notes on arboricultural and agricultural practices in ancient Iran based on new pollen evidence. Paléorient 36: 175-188.

497 Gerasimov, I.P. (ed.)

4981964 Physico-Geographical Atlas of the World. GUGK, Moscow (in Russian).

499 GULISASHVILI, V.Z.

5001964 Natural zones and eco-historical districts of the Caucasus. Nauka, Moscow (in 501 Russian).

502 HOVSEPYAN, R.

5032011 Palaeoethnobotanical data from the high mountainous Early Bronze Age settlement of Tsaghkasar-1 (Mt. Aragats, Armenia). Ethnobiology Letters 2: 5862 .

506 this volume On the agriculture and vegetal food economy of Kura-Araxes culture in 507 the South Caucasus. Paléorient.

508 Johnnin, S., Ali, A.A., Ollivier, V., Roiron, P., Peyron, O., Chevaux, S.,

509 Nahapetyan, S., Tozalakyan, P., Karakhanyan, A. and Chataigner, C.

5102014 Vegetation, fire and climate history of the Lesser Caucasus: a new Holocene 511 record from Zarishat fen (Armenia). Journal of Quaternary Science 29: 70-82.

512 Kakhiani, K., Sagona, S., Sagona, C., Kvavadze, E., Bedianashvili, G.,

513 Massager, E., Martin, L., Herrscher, E., Martkoplishvili, I., Birkett-Rees, J. and 514 LONGFORD, C.

5152013 Archaeological investigations at Chobareti in southern Georgia, the Caucasus. $516 \quad$ Ancient Near Eastern Studies 50: 1-138.

517 Karakhanian, A., Djrbashian, R., Trifonov, V., Philip, H., Arakelian, S. and 518 AVAgIAN, A. 
2002 Holocene-historical volcanism and active faults as natural risk factors for Armenia and adjacent countries. Journal of Volcanology and Geothermal Research 113: 319-344.

\section{KETSKHOVELI, N.}

1959 Cultural vegetation zones of Georgia. Metsniereba, Tbilisi (in Georgian).

\section{KUSHNAREVA, K.K.}

1997 The Southern Caucasus in Prehistory. University Museum, University of Pennsylvania, Philadelphia.

\section{KVAVADZE, E.V.}

1993 On the interpretation of subfossil spore-pollen spectra in the mountains. Acta Palaeobotanica 33: 347-360.

1999 Holocene fluctuations of the Lisi Lake level and the shift of the lower forest line. In: MCHELIDZE, G. (ed) Problems of Palaeobiology 1: 75-87. Institute of Paleobiology, Tbilisi.

\section{Kvavadze, E.V., BuKREEVA, G.F. and RuKhadze, L.P}

1992 Komp'iuternaia tekhnologia rekonstruktsii paleogeograficheskikh rekonstruksii $v$ gorakh (na primere golotsena Abkhazii). Metsniereba, Tbilisi.

\section{KVAVADZE, E.V. and KAKHIANI, K.}

2010 Palynology of the Paravani burial mound (Early Bronze Age, Georgia). Vegetation History and Archaeobotany 19: 469-478.

Kvavadze, E., Shatberashvili, Z., Amiranashvili, J. and Arabuli, G.

2004 Palynological investigations of two burial mounds of the Middle Bronze Age of Tkemlara (southern Georgia). Acta Palaeobotanica 44: 267-279.

Leroy, S.A.G., KaKroodi, A.A., KroOnenberg, S., LAHiJani, H.K., AlimoHammadian, H. and Nigarov, A.

2013 Holocene vegetation history and sea level changes in the SE corner of the Caspian Sea: relevance to SW Asia climate. Quaternary Science Reviews 70: 2847.

Litt, T., Krastel, S., Sturm, M., Kipfer, R., Örcen, S., Heumann, G., Franz, S.O., Ülgen, U.B. and NiESSEN, F.

2009 'Paleovan', International Continental Scientific Drilling Program (ICDP): site survey results and perspectives. Quaternary Science Reviews 28: 1555-1567.

\section{LONGFord, C., Drinnan, A. and SAgOna, A.}

2009 Archaeobotany of Sos Höyük, northeast Turkey. In: FAIRBAIRn, A., O'ConNOR, S., MARwick, B. (eds.) New Directions in Archaeological Science: 121-136. ANU e-Press, Canberra (Terra Australis 28). 
1995 History of the Holocene Vegetation of Georgia. Metsniereba, Tbilisi (in Russian).

Messager, E., Belmecheri, S., Von Grafenstein, U., Nomade, S., Ollivier, V., Voinchet, P., Puaud, S., Courtin-Nomade, A., Guillou, H., Mgeladze, A., Dumoulin, J.-P., MAZUY, A. and LORDKIPANidZE, D.

2013 Late Quaternary record of the vegetation and catchment-related changes from Lake Paravani (Javakheti, South Caucasus). Quaternary Science Reviews 77: 125-140.

Myers, N., Mittermeier, R., Mittermeier, C.G., DA FonsecA, G.A.B. and Kent, J. 2000 Biodiversity hotspots for conservation priorities. Nature 403: 863-858.

NAKHUTSRISHVILI, G.S.

1999 The vegetation of Georgia (Caucasus). Braun-Blanquetia 15: 1-68.

\section{NEWTON, J.}

2004 Life in the Mountains of Anatolia: a study of a Bronze Age settlement in its environmental context. PhD thesis, School of Geography, Anthropology and Environmental Studies, University of Melbourne.

Ponel, P., Andrieu-Ponel, V., DJamali, M., LahiJani, H., Leydet, M. and MASHKOUR, M.

2103 Fossil beetles as possible evidence for transhumance during the middle and late Holocene in the high mountains of Talysch (Talesh) in NW Iran? Journal of Environmental Archaeology 18: 201-210.

Ramezani, E., Marvie Mohadjer, M.R., KnaAp, H.-D., Ahmadi, H. and Joosten, H. 2008 The late-Holocene vegetation history of the Central Caspian (Hyrcanian) forests of northern Iran. The Holocene 18: 307-321.

Ramezani, E., Marvie Mohadjer, M.R., KnaAp, H.-D., Theuerkauf, M., Manthey, M. and Joosten, $\mathrm{H}$.

2013 Pollen-vegetation relationships in the central Caspian (Hyrcanian) forests of northern Iran. Review of Palaeobotany and Palynology 189: 38-49.

ROBERTS, N.

2002 Did prehistoric landscape management retard the post-glacial spread of woodland in Southwest Asia? Antiquity 76: 1002-1010.

Roberts, N., Eastwood, W.J., KuZucuoĞLu, C., Florentino, G. and Caracuta, V. 2011 Climatic, vegetation and cultural change in the eastern Mediterranean during the mid-Holocene environmental transition. The Holocene 21: 147-162.

ROBERTS, N. and WRIGHT, H.E.

1993 Vegetational, lake-level and climatic history of the Near East and Southwest Asia. In: Wright, H.E., KutZBACH, J.E., WebB, T., RudDimAn, W.F., StREet- 
SAGONA, A.

2011 Anatolia and the Transcaucasus - themes and variations ca. $6400-1500$ B.C.E. In: Steadman, S.R. and McMahon, G. (eds.) Ancient Anatolia: 10,000-323 B.C.E.: 683-703. Oxford University Press, Oxford.

this volume Rethinking the Kura-Araxes genesis. Paléorient.

SAIADIAN, Y.

1985 Sevan - the natural 'climatograph' of the Holocene. In: Problems in Holocene Geology (XI INQUA Congress, Moscow): 61-67. Izdat. AN ACCR, Yerevan (in Russian).

1999 Natural conditions and humans in the Lake Sevan basin during the middle and late Holocene. Bulletin of the Russian Geographical Society 131 (4): 55-66 (in Russian).

Shumilovskikh, L.S., Tarasov, P., Arz, H.W., Fleitmann, D., Marret, F., Nowaczyk, N., Plessen, B., SchlÜtz, F. and Behling, H.

2012 Vegetation and environmental dynamics in the southern Black Sea region since 18 kyr BP derived from the marine core 22-GC3. Palaeogeography, Palaeoclimatology, Palaeoecology 337/338: 117-193.

SteVEnS, L.R., Wright, H.E. and ItO, E.

2001 Proposed changes in seasonality of climate during the Lateglacial and Holocene at Lake Zeribar, Iran. The Holocene 11: 747-755.

TAKHTAJAN, A.

1986 Floristic Regions of the World. University of California Press, Berkeley.

\section{TÜRKEȘ, M.}

1996 Spatial and temporal analysis of annual rainfall variations in Turkey.

$$
\text { International Journal of Climatology 16: 1057-1076. }
$$

\section{TURNEY, C.S.M. and BROwn, H.}

2007 Catastrophic early Holocene sea level rise, human migration and the Neolithic transition in Europe. Quaternary Science Reviews 26: 2036-2041.

TwEDDLE, J.C., EDWARDS, K.J. and FIELLER, N.R.J.

2005 Multivariate statistical and other approaches for the separation of cereal from wild Poaceae pollen using a large Holocene dataset. Vegetation History and Archaeobotany 14: 15-30.

VAN ZEIST, W. and BoTTEMA, S.

1991 Late Quaternary Vegetation of the Near East. Dr Ludwig Reichert Verlag, Weisbaden. 
650

651

VAN ZEIST, W . and WOLDRING, H.

1978 A postglacial pollen diagram from Lake Van in East Anatolia. Review of Palaeobotany and Palynology 26: 249-276.

WALTER, H.

1974 Die Vegetation Osteuropas, Nord- und Zentralasiens. Fischer, Stuttgart.

Weninger, B., Alram-Stern, E., Bauer, E., Clare, L., Danzeglocke, U., Jöris, O., Kubatzki, C., Rollefson, G., Todorova, H. and VAn Andel, T.

2006 Climate forcing due to the $8200 \mathrm{cal}$ yr BP event observed at Early Neolithic sites in the eastern Mediterranean. Quaternary Research 66: 401-420.

WICK, L., LEMKE, G. and STURM, M.

2003 Evidence of Lateglacial and Holocene climatic change and human impact in Eastern Anatolia: high-resolution pollen, charcoal, isotopic and geochemical records from the laminated sediments of Lake Van, Turkey. The Holocene 13: 665-675.

WOLDRING, H. and CAPPERS, $\mathrm{H}$.

2001 The origin of the 'wild orchards' of Central Anatolia. Turkish Journal of Botany 25: $1-9$.

YILMAZ, Y., GÜNER, Y. and ŞAROĞLU, F.

1998 Geology of the Quaternary volcanic centres of the East Anatolia. Journal of Volcanology and Geothermal Research 85: 173-210.

ZOHARY, M.

652 
654 Table 1 - Details of pollen sites indicated in Fig. 1.

\begin{tabular}{|l|l|l|l|l|l|}
\hline No. & Site & $\begin{array}{l}\text { Lat., Long. } \\
\text { (decimal } \\
\text { degrees) }\end{array}$ & $\begin{array}{l}\text { Elevation } \\
\text { (m above } \\
\text { sea level) }\end{array}$ & Evidence & Reference \\
\hline 1 & Aligol, GE & $41.63 \mathrm{~N}, 44.02 \mathrm{E}$ & 1550 & $\begin{array}{l}\text { Pollen, micro- } \\
\text { charcoal }\end{array}$ & $\begin{array}{l}\text { Connor \& Sagona } \\
2007\end{array}$ \\
\hline 2 & Almalou, Iran & $37.66 \mathrm{~N}, 46.63 \mathrm{E}$ & 2500 & Pollen & $\begin{array}{l}\text { Djamali et al. 2009, } \\
2011\end{array}$ \\
\hline 3 & Cheliagele, GE & $42.47 \mathrm{~N}, 43.10 \mathrm{E}$ & 1100 & $\begin{array}{l}\text { Pollen, micro- } \\
\text { charcoal }\end{array}$ & Ammann 2010 \\
\hline 4 & Didajara, GE & $41.68 \mathrm{~N}, 42.50 \mathrm{E}$ & 1850 & Pollen & Margalitadze 1995 \\
\hline 5 & Gomnistba, GE & $41.77 \mathrm{~N}, 43.35 \mathrm{E}$ & 1850 & Pollen & Margalitadze 1995 \\
\hline 6 & Imera, GE & $41.65 \mathrm{~N}, 44.22 \mathrm{E}$ & 1610 & $\begin{array}{l}\text { Pollen, micro- } \\
\text { charcoal }\end{array}$ & $\begin{array}{l}\text { Connor \& Sagona } \\
2007\end{array}$ \\
\hline 7 & Ispani, GE & $41.85 \mathrm{~N}, 41.78 \mathrm{E}$ & 2 & $\begin{array}{l}\text { Pollen, micro- } \\
\text { charcoal }\end{array}$ & $\begin{array}{l}\text { Connor et al. 2007; } \\
\text { de Klerk et al. 2009 }\end{array}$ \\
\hline 8 & Paravani, GE & $41.45 \mathrm{~N}, 43.80 \mathrm{E}$ & 2075 & $\begin{array}{l}\text { Pollen, } \\
\text { geochemistry }\end{array}$ & $\begin{array}{l}\text { Messager et al. } \\
2013\end{array}$ \\
\hline 9 & Pasinler, Turkey & $39.98 \mathrm{~N}, 41.70 \mathrm{E}$ & 1690 & Pollen, organics & Collins et al. 2005 \\
\hline 10 & Sevan, AR & $40.53 \mathrm{~N}, 44.98 \mathrm{E}$ & 1900 & Pollen & Saiadian 1985 \\
\hline 11 & Söğütlü, Turkey & $38.65 \mathrm{~N}, 42.08 \mathrm{E}$ & 1500 & Pollen & Bottema 1995 \\
\hline 12 & Tsavkisi, GE & $41.68 \mathrm{~N}, 44.72 \mathrm{E}$ & 1100 & $\begin{array}{l}\text { Pollen, micro- } \\
\text { charcoal }\end{array}$ & $\begin{array}{l}\text { Connor \& } \\
\text { Kvavadze 2005 }\end{array}$ \\
\hline 13 & Urmia, Iran & $37.63 \mathrm{~N}, 45.38 \mathrm{E}$ & 1300 & $\begin{array}{l}\text { Pollen, } \\
\text { geochemistry } \\
\text { Pollen, isotopes }\end{array}$ & Bottema 1986 \\
\hline 14 & Van, Turkey & $38.42 \mathrm{~N}, 42.67 \mathrm{E}$ & 1650 & $\begin{array}{l}\text { Pollen, macro- } \\
\text { charcoal }\end{array}$ & Joannin et al. 2014 \\
\hline 15 & Zarishat, AR & $40.99 \mathrm{~N}, 43.67 \mathrm{E}$ & 2120 & & \\
\hline
\end{tabular}


Table 2 - Estimates of climatic conditions at 3000 BC in the Kura-Araxes region derived from quantitative palaeoclimatic reconstructions of pollen records. Values are given relative to the recent climate. Reconstruction methods include regression modelling (RM), weighted averaging (WA) and the modern analogue technique (MAT). These estimates should be used with caution, 661 as both climatic and non-climatic factors influence pollen records.

\begin{tabular}{|c|c|c|c|c|}
\hline $\begin{array}{l}\text { Site (and number } \\
\text { in Fig. 1) }\end{array}$ & $\begin{array}{l}\text { Palaeoclimatic } \\
\text { variable }\end{array}$ & $\begin{array}{l}\text { Reconstructed climate at } \\
3000 \mathrm{BC} \text { relative to late } \\
\text { 20th century AD }\end{array}$ & Method & Source \\
\hline $\begin{array}{l}\text { Abkhazia, NW } \\
\text { Caucasus }\end{array}$ & $\begin{array}{l}\text { Tree-line } \\
\text { position }\end{array}$ & $\begin{array}{l}\text { Up to } 300 \mathrm{~m} \text { higher (i.e. } \\
\text { warmer temperatures) }\end{array}$ & RM & $\begin{array}{l}\text { Kvavadze et al. } \\
1992\end{array}$ \\
\hline Aligol, GE (1) & $\begin{array}{l}\text { Mean annual } \\
\text { rainfall }\end{array}$ & $40 \pm 55 \mathrm{~mm} / \mathrm{a}$ lower & WA & $\begin{array}{l}\text { Connor \& } \\
\text { Kvavadze } 2008\end{array}$ \\
\hline Cheliagele, GE (3) & $\begin{array}{l}\text { Mean annual } \\
\text { rainfall }\end{array}$ & $645 \pm 70 \mathrm{~mm} / \mathrm{a}$ higher & WA & $\begin{array}{l}\text { Connor \& } \\
\text { Kvavadze } 2008\end{array}$ \\
\hline Didajara, GE (4) & $\begin{array}{l}\text { Mean annual } \\
\text { rainfall }\end{array}$ & $430 \pm 80 \mathrm{~mm} / \mathrm{a}$ higher & WA & $\begin{array}{l}\text { Connor \& } \\
\text { Kvavadze } 2008\end{array}$ \\
\hline Gomnistba, GE (5) & $\begin{array}{l}\text { Mean annual } \\
\text { rainfall }\end{array}$ & $240 \pm 75 \mathrm{~mm} / \mathrm{a}$ higher & WA & $\begin{array}{l}\text { Connor \& } \\
\text { Kvavadze } 2008\end{array}$ \\
\hline Imera, GE (6) & $\begin{array}{l}\text { Mean annual } \\
\text { rainfall }\end{array}$ & $15 \pm 55 \mathrm{~mm} / \mathrm{a}$ higher & WA & $\begin{array}{l}\text { Connor \& } \\
\text { Kvavadze } 2008\end{array}$ \\
\hline Ispani, GE (7) & $\begin{array}{l}\text { Mean annual } \\
\text { rainfall }\end{array}$ & $110 \pm 150 \mathrm{~mm} / \mathrm{a}$ lower & WA & $\begin{array}{l}\text { Connor \& } \\
\text { Kvavadze } 2008\end{array}$ \\
\hline Tsavkisi, GE (12) & $\begin{array}{l}\text { Mean annual } \\
\text { rainfall }\end{array}$ & $140 \pm 65 \mathrm{~mm} / \mathrm{a}$ lower & WA & $\begin{array}{l}\text { Connor \& } \\
\text { Kvavadze } 2008\end{array}$ \\
\hline Zarishat, AR (15) & Winter rainfall & $\begin{array}{l}15 \mathrm{~mm} \text { lower to } 10 \mathrm{~mm} \\
\text { higher }\end{array}$ & MAT & $\begin{array}{l}\text { Joannin et al. } \\
2014\end{array}$ \\
\hline Zarishat, AR (15) & $\begin{array}{l}\text { May-June } \\
\text { rainfall }\end{array}$ & $\begin{array}{l}5 \mathrm{~mm} \text { lower to } 25 \mathrm{~mm} \\
\text { higher }\end{array}$ & MAT & $\begin{array}{l}\text { Joannin et al. } \\
2014\end{array}$ \\
\hline Zarishat, AR (15) & $\begin{array}{l}\text { Mean temp. of } \\
\text { coldest month }\end{array}$ & $5.5-11.5^{\circ} \mathrm{C}$ warmer & MAT & $\begin{array}{l}\text { Joannin et al. } \\
2014\end{array}$ \\
\hline
\end{tabular}




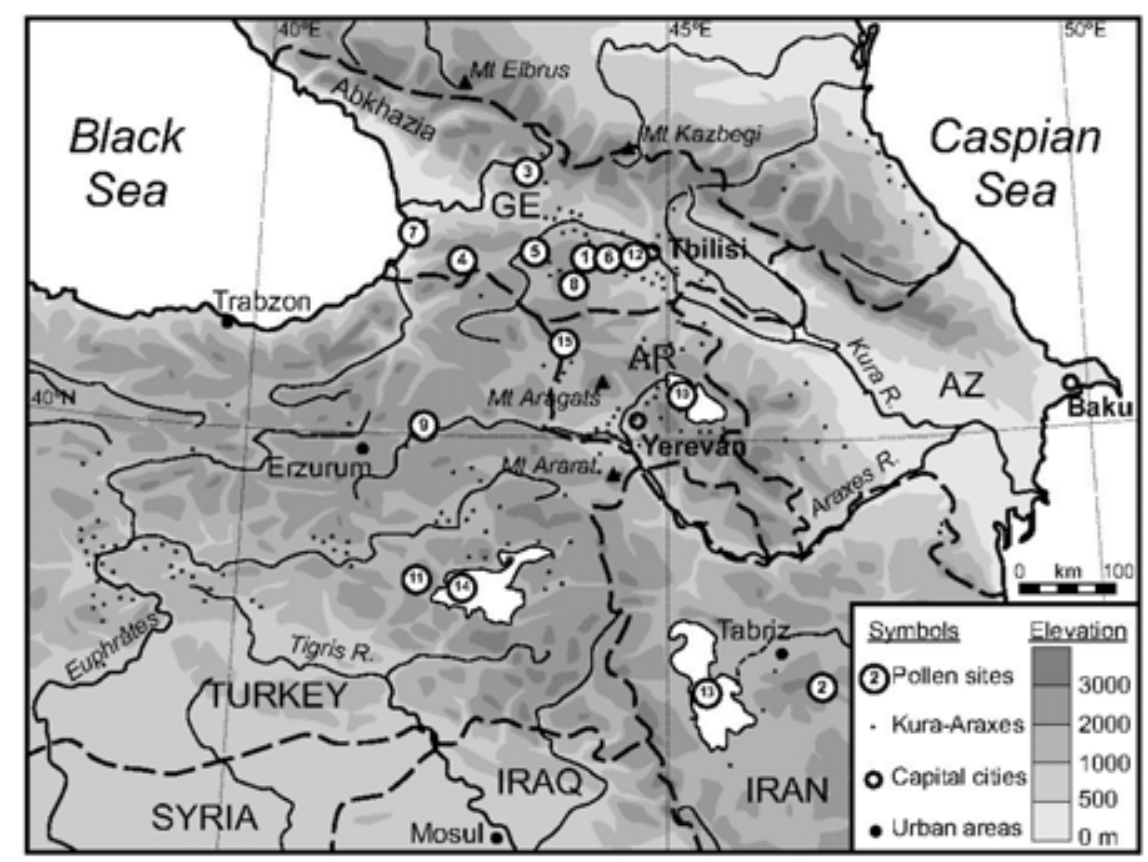

666

667

668

669

670

Fig. 1 - Map of the mountainous region where the Kura-Araxes culture developed in the $4^{\text {th }}-3^{\text {rd }}$ millennia BC. Evidence for past climate and vegetation comes primarily from the pollen sites listed in Table 1. Kura-Araxes site locations follow Kushnareva (1997). Country abbreviations: AR - Armenia; AZ - Azerbaijan; GE - Georgia.

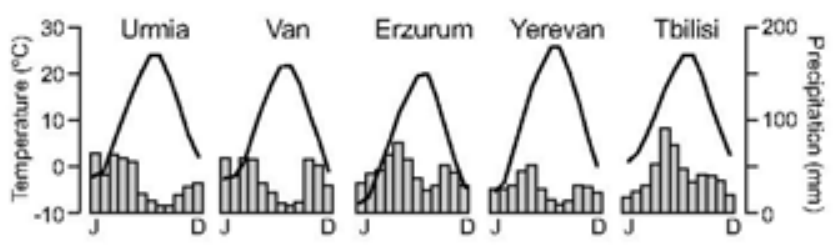

671

672

Fig. 2 - Climate graphs for selected locations in the Kura-Araxes region, showing changes in

673 rainfall seasonality from south (Urmia) to north (Tbilisi). Line graphs represent monthly

674 average temperatures and histograms represent monthly average precipitation from January $(\mathrm{J})$

675 to December (D). Modified from Gerasimov (1964). 

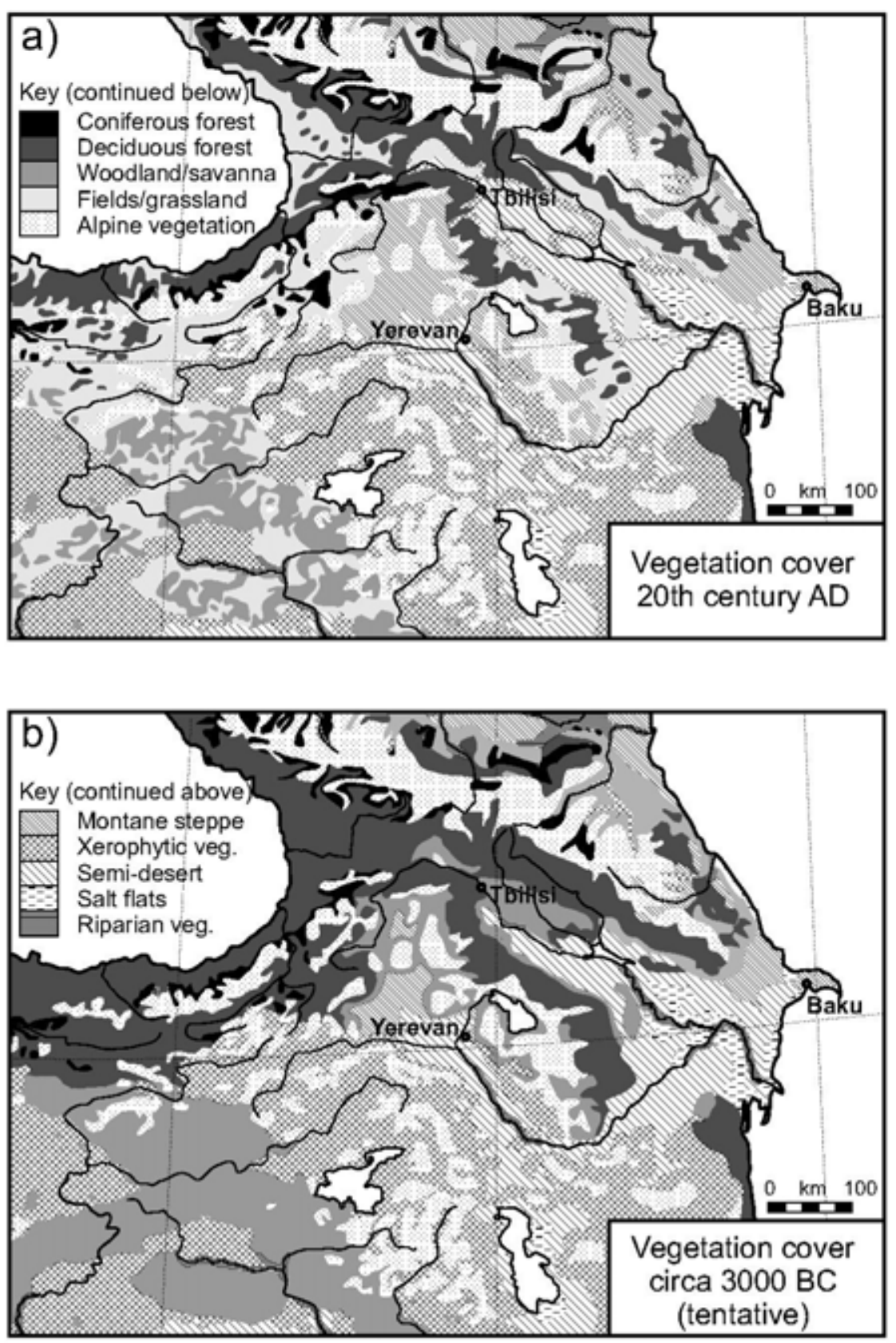

678 Fig. 3 - Vegetation map of the Kura-Araxes region (a) in the mid-20 $0^{\text {th }}$ century, and (b) a

679 tentative reconstruction at approximately $3000 \mathrm{BC}$ based on interpretation of pollen records and 680 bioclimatic zones. The map should be viewed only as a possible representation of past

681 conditions and is probably unreliable for areas distant from the pollen sites in Fig. 1. Modified from 'Vegetation Map of the USSR' (Karta Rastitel'nosti SSSR), GUGK (1956). 


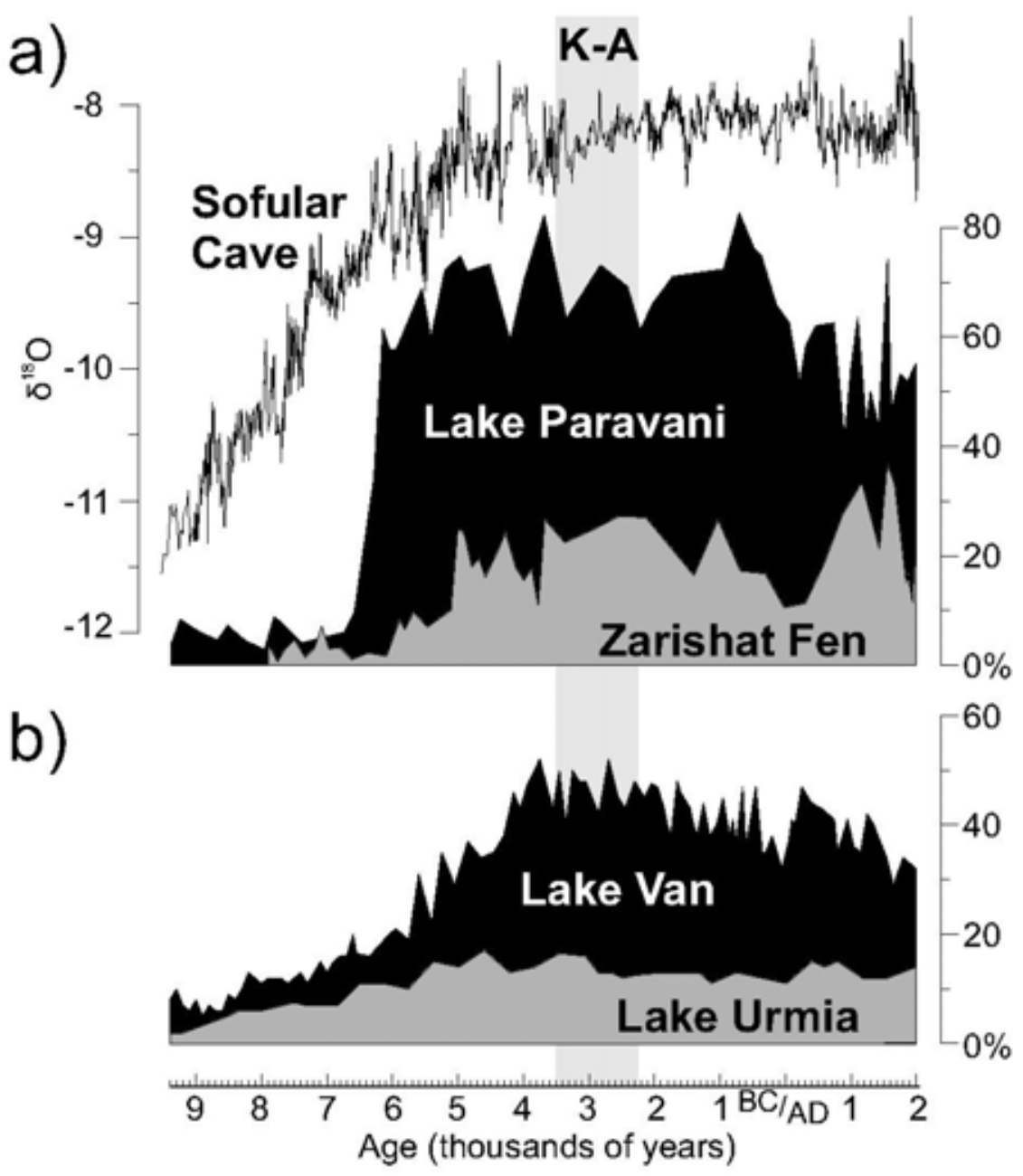

Fig. 4 - Changes in tree pollen abundance at four key sites since the beginning of the Holocene, showing the slow advance of forest vegetation after the last glacial period and its full development by the time of the Kura-Araxes culture: a) northern sites in Georgia and Armenia; b) southern sites in Turkey and Iran. The oxygen isotope record from the Sofular Cave stalagmite is shown at top, indicating a less variable climate during the Kura-Araxes period compared to previous millennia. Data from Bottema (1986), Badertscher et al. (2011), Messager et al. (2013) and Joannin et al. (2014). 


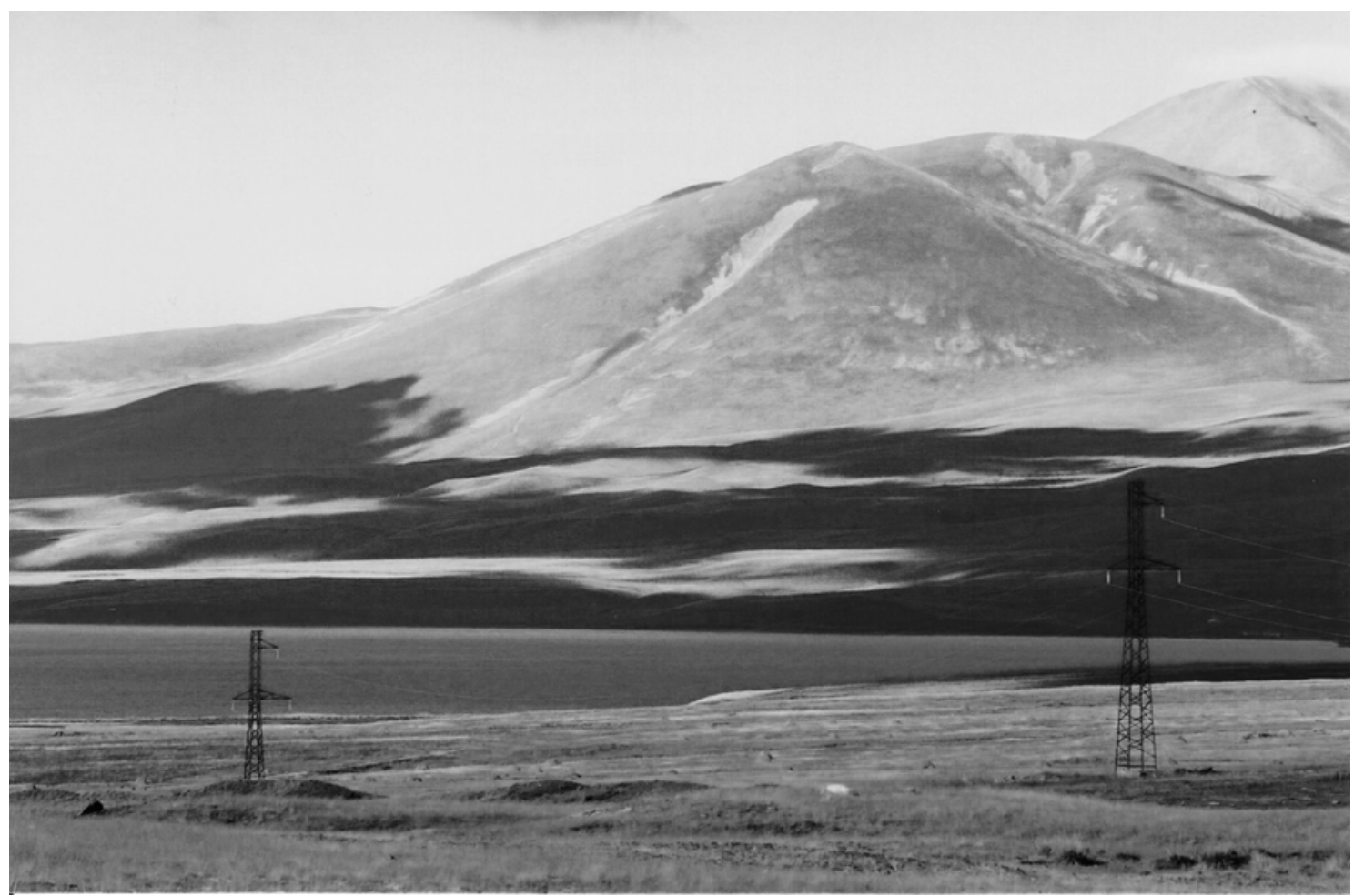

Fig. 5 - Lake Paravani and Mt Patara Abuli in Southern Georgia. Pollen evidence from this lake suggests that trees (probably pines) grew on the lower slopes around the lake during the KuraAraxes period (Messager et al., 2013). Photo: S. Connor.

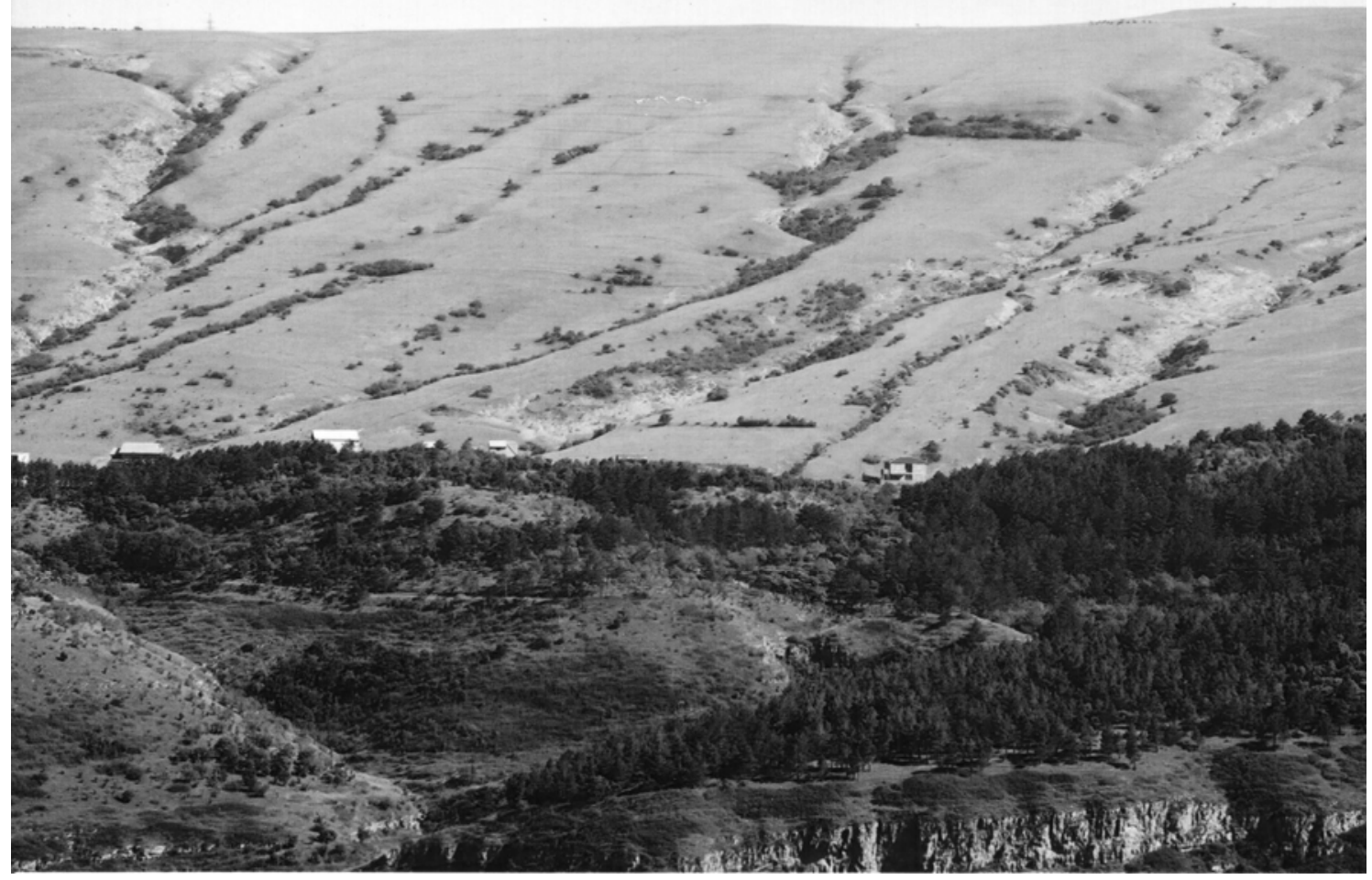

697 Fig. 6 - The hills around Tsavkisi Wetland, near Tbilisi. Pollen evidence from this area

698 demonstrates that these hills were covered with oak-ash forests during the $3^{\text {rd }}$ millennium BC

699 (Connor \& Kvavadze, 2005). Forests retreated in the $2^{\text {nd }}$ millennium BC due to changing

700 climates and land-use practices. The forested areas in the lower part of the photograph are $20^{\text {th }}$ -

701 century pine plantations. Photo: S. Connor. 


\section{University Library}

\section{- M M I E E R VA A gateway to Melbourne's research publications}

Minerva Access is the Institutional Repository of The University of Melbourne

Author/s:

Connor, SE;Kvavadze, EV

Title:

Environmental context of the Kura-Araxes culture

Date:

2014

Citation:

Connor, S. E. \& Kvavadze, E. V. (2014). Environmental context of the Kura-Araxes culture.

Paléorient, 40, pp.9-20

Persistent Link:

http://hdl.handle.net/11343/55222 